\title{
HHV8 ORF74 Gene
}

National Cancer Institute

\section{Source}

National Cancer Institute. HHV8 ORF74 Gene. NCI Thesaurus. Code C114504.

HHV8 ORF74, which encodes viral G-protein coupled receptor protein, is involved in the modulation of cell proliferation, cell migration, angiog enesis and cell survival. 